\title{
Acknowledging the skill needed to succeed
}

\author{
Abe DeAnda, Jr, MD, and Vincent R. Conti, MD
}

\author{
From the Division of Cardiovascular and Thoracic Surgery, UTMB-Galveston, Galveston, Tex. \\ Disclosures: Authors have nothing to disclose with regard to commercial support. \\ Received for publication March 29, 2018; accepted for publication March 29, 2018; available ahead of print April \\ 24, 2018. \\ Address for reprints: Abe DeAnda, Jr, MD, Division of Cardiothoracic Surgery, UTMB-Galveston, 301 Univer- \\ sity Blvd, Galveston, TX 77555 (E-mail: abdeanda@utmb.edu). \\ J Thorac Cardiovasc Surg 2018;156:87-8 \\ $0022-5223 / \$ 36.00$ \\ Copyright (C) 2018 by The American Association for Thoracic Surgery \\ https://doi.org/10.1016/j.jtcvs.2018.03.134
}

More than 50 years has passed since the first description of replacement of the aortic valve with an autologous pulmonic valve ${ }^{1}$ and the subsequent modification (with the addition of a homograft in the pulmonary position) and popularization of the procedure by Ross. ${ }^{2}$ The procedure has had its share of proponents and detractors, and it has never achieved widespread adoption. A review by Reece and colleagues ${ }^{3}$ of all Ross procedures entered into the Society of Thoracic Surgeons Adult Cardiac Surgery Database for the years 1994 through 2010 showed that by 2010, the Ross procedure accounted for only $0.09 \%$ of all aortic valve replacements; a quarter of all Ross procedures were performed at 6 sites; and only 9 sites averaged 5 or more Ross procedures per year. This Society of Thoracic Surgeons database analysis also noted an operative mortality of $2.7 \%$ and a reexploration rate of $9.4 \%{ }^{3}$ Relationships between surgeon (and institution) volume and outcomes have been described for aortic surgery, including aortic root replacement ${ }^{4}$ and aortic valve surgery, ${ }^{5}$ so it does not come as a surprise that the same may be true for the Ross procedure.

In their article in this issue of the Journal analyzing valve performance with the Ross procedure in a 22-year period, Sievers and colleagues ${ }^{6}$ report 630 cases, with a perioperative mortality of $0.3 \%$ and a long-term survival equivalent to that of the general population. Several other institutions have reported excellent results, ${ }^{7-9}$ similar to those of Sievers and colleagues, ${ }^{6}$ and long-term results superior to those seen with mechanical valves. ${ }^{7-9}$ These singleinstitution results have inspired editorials and expert opinion statements ${ }^{10}$ advocating a significant increase in the use of the Ross procedure, particularly for young and middle-aged adults.

To justify this approach, one must achieve excellent early results and adopt techniques that prevent late failure, which most frequently occurs as a result of progressive dilatation of the neoaortic root. This proximal dilatation can be ameliorated by prosthetic or autologous external reinforcement or by the use of the subcoronary root surgery.

\section{References} 2014;97:175-81.

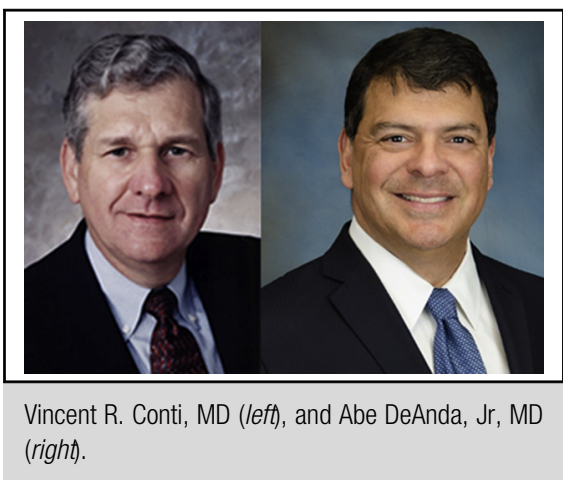

Central Message

Excellent results from select institutions should encourage the continued use of the Ross procedure, with the caveat that these results require technical expertise.

See Article page 79.

technique, as originally described by $\operatorname{Ross}^{2}$ and used by Sievers and colleagues. ${ }^{6}$ These techniques are technically demanding and require the operation to be performed by surgeons who can maintain a large clinical volume of these procedures and are technically skilled with aortic

The outcomes noted by Sievers, as well as the tool created to evaluate the performance of the valve, are to be congratulated. They have set a bar that most likely few will be able to meet. Given the Society of Thoracic Surgeons data showing only 9 centers with 5 or more annual cases, this is not surprising. Every surgeon's case series begins with an $\mathrm{n}$ of 1 ; to develop the required expertise will require mentoring and hands-on training by those proficient in the procedure. Increased use of the Ross procedure may result in some surgeons' development of the technical expertise to match the results of Sievers and colleagues. ${ }^{6}$ In the meantime, however, this procedure should probably be relegated to those who already do it well.

1. Pillsbury RC, Shumway NE. Replacement of the aortic valve with the autologous pulmonic valve. Surg Forum. 1966;17:176-7.

2. Ross DN. Replacement of the aortic and mitral valves with a pulmonary autograft. Lancet. 1967;2:956-8.

3. Reece TB, Welke KF, O'Brien S, Grau-Sepulveda MV, Grover FL, Gammie JS. Rethinking the Ross procedure in adults. Ann Thorac Surg.

4. Hughes GC, Zhao Y, Rankin JS, Scarborough JE, O'Brien S, Bavaria JE, et al. Effects of institutional volumes on operative outcomes for aortic root replacement in North America. J Thorac Cardiovasc Surg. 2013;145:166-70. 
5. Dewey TM, Herbert MA, Ryan WH, Brinkman WT, Smith R, Prince SL, et al. Influence of surgeon volume on outcomes with aortic valve replacement. Ann Thorac Surg. 2012;93:1107-12; discussion 1112-3.

6. Sievers HH, Stierle U, Petersen M, Klotz S, Richardt D, Diwoky M, et al. Valve performance classification in 630 subcoronary Ross patients over 22 years. J Thorac Cardiovasc Surg. 2018:156:79-86.

7. Buratto E, Shi WY, Wynne R, Poh CL, Larobina M, O'Keefe M, et al. Improved survival after the Ross procedure compared with mechanical aortic valve replacement. J Am Coll Cardiol. 2018;71:1337-44.
8. Martin E, Mohammadi S, Jacques F, Kalavrouziotis D, Voisine P, Doyle D, et al. Clinical outcomes following the Ross procedure in adults: a 25-year longitudinal study. J Am Coll Cardiol. 2017;70:1890-9.

9. Mazine A, David TE, Rao V, Hickey EJ, Christie S, Manlhiot C, et al. Long-term outcomes of the Ross procedure versus mechanical aortic valve replacement: propensity-matched cohort study. Circulation. 2016;134:576-85.

10. Ouzounian M, Mazine A, David TE. The Ross procedure is the best operation to treat aortic stenosis in young and middle-aged adults. J Thorac Cardiovasc Surg. $2017 ; 154: 778-82$. 